\title{
LOS DOS CONCEPTOS DE LA UNIVERSIDAD*
}

\author{
Raúl Silva Castro
}

El concepto clásico

En Chile se echado mano numerosas veces de un modo de expresión típico de cuanto hasta el presente significa la Universidad (al menos entre nosotros): se ha hablado de "claustro universitario". Realmente la idea clásica que se puede aludir cuando se trata de la Universidad es la de un cónclave de sabios diplomados y en posesión de la verdad absoluta e inconmovible que tratan de imponerse a todos los pobres alumnos que caen bajo su jurisdicción.- La Universidad claustral ha conservado en la mayor parte de los países que aún la soportan todo un arsenal protocolar complicado e inútil. La ceremonia de "colación de grados" en un colegio universitario inglés, por ejemplo, tiene todos los visos de un acontecimiento medioeval: relucen los bordados y se desentierran las pelucas postizas....; hay tribunales, juramentos e imposiciones de órdenes...todo un aparato, en una palabra, que parece haberse producido en forma idéntica a la presente en los días obscuros de la ardorosa Edad Media.

Y sin embargo, en sus comienzos, la Universidad poseyó un espíritu abierto, democrático, semejante en un todo al que se pugna hoy por imprírsele. Se reunían en los albores del siglo duodécimo los maestros y los discípulos empeñados en la prosecución de un mismo fin: el conocimiento de las ciencias y de la filosofía, y de allí nació la institución que, andando el tiempo, había de ser designada con el nombre de Universidad, queriéndose señalar con él la comprensión que ella hacía de todos los ramos del saber humano. Y así como la Universidad ha ido despojándose de ese carácter algo exagerado de omni-comprensión, ha ido perdiendo también con el correr de los años aquella originaria desenvoltura democrática, aquel alternar sosegado de discípulos y maestros -que recuerda los años esplendorosos de Atenas-, para adquirir rigidez dogmática y férrea disciplina.

Cuando no unía a los alumnos y a los maestros de las Universidades sino el deseo infinito de saber, no había grados y eran libres la docencia y la asistencia; entonces convergían de los puntos mas distantes de los pueblos, atravesando a veces las vagas fronteras nacionales, todos los que querian recibir las lecciones sabias de filósofos y hombres de ciencia. Fue ese afluir excesivo, desbordante, el que creó poco a poco la necesidad de establecer en las aulas universitarias, libres en un comienzo, las normas de disciplinas y el escalafón inexorable que hasta el

Este texto, que se presenta íntegro, fue publicado por primera vez el 24 de junio de 1922 en la revista Claridad, año II, No 57, de la FECH (Federación de Estudiantes de la Universidad de Chile). (N. del. E.) 
momento actual se perpetúan. Se crearon entonces los bachilleres, los licenciados después y finalmente los doctores, trayendo consigo este aparato titular una organización especial destinada a catalogar los alumnos según los diversos grados.

Pero no se habría dicho sino una parte -las más importante eso si- de la verdad si se callara la trascendencia que tuvo en la creación del espíritu cerrado y exclusivista de la Universidad el que estuviera durante siglos supeditada al influjo dominante de las órdenes religiosas. Hubo años en la Edad Media en que Universidad y Monasterio eran sinónimos, así como decir fraile era decir letrado, erudito y filósofo. De esa confusión es de donde más tomó la Universidad los gérmenes de la rigidez que todos le han conocido, verdadera supervivencia escolástica en que la letra ha aniquilado al espirítu. El Estado vino a intervenir muchos años mas tarde, siendo en general su acción enmarcada por el afán de conservar todos los viejos alardes docentes, así como por el deseo de depositar en los maestros universitarios una alta representación política encaminada casi siempre a brindarles prestigio científico...

\section{El concepto moderno}

Un hecho primordial se puede anotar en la evolución más reciente de las instituciones universitarias: la mayor independencia de las facultades. Hoy en día cada facultad tiene no sólo un cuerpo autónomo de profesores encargados de aleccionar a alumnos especialistas, sino que también funcionan sus cursos en locales separados, no existiendo entre las diversas facultades más liámen que la organización superior que las funde en una Universidad por medio de representaciones ante los cuerpos directivos de ésta. La Universidad, pues ha cambiado en su estructura misma; el reconocimiento de cada facultad como tal -independiente, autónoma para todos los asuntos en que dichas calidades pueden subsistir-, ha tenido necesariamente que involucrar un cambio en la idea de Universidad. De organismo más o menos pesado, rígido, ha venido a ser un compuesto de partes diferenciadas y con vida propia, lo que ha traído como una consecuencia indirecta una mayor penetración de la Universidad por todas aquellas corrientes ideológicas que no la han reconocido como directora en su formación siendo por eso mucho más libres y ajenas a los dogmatismos didácticos.

Más modernamente aún, en nuestros propios días, se ha querido introducir en la Universidad elementos nuevos destinados a aumentar la democratización de las corporaciones más latas en la estructura educacional de un pueblo; y esos anhelos que ya han triunfado -más o menos plenamente- en algunos países, consisten en dar representación a los alumnos en los organismos directivos de las instituciones universitarias y en asegurar para los que puedan ser maestros la docencia libre, así como para los alumnos la libre asistencia. La Universidad, sin metáfora, se independiza como en otro tiempo se independizaron los pueblos americanos de la opresora tutela hispana. La Universidad se proclama libre 
intelectualmente, se aleja el tutelaje de los gobiernos empeñados en rugir la ciencia como si ellas fuese facturado; quiere bastarse a sí propia vida fecunda y potente que ha de subsistir sin ajenos auxilios.

En su esencia, el movimiento de la reforma universitaria implica toda una democratización de los instrumentos necesarios para adquirirla.- La Universidad nueva, reformada, es una cosa viva, plástica, flexible; ha dejado de ser la fría máquina encargada de fabricar profesionales y la oficina de despacho de los títulos anhelados...; la Universidad nueva coge los espíritus sanos, robustos, de los hombres y los educa sin desviarlos, los alecciona sin despotismo, los dignifica y los exalta.

Este movimiento de reforma de las instituciones universitarias es para Chile de una imprescindible necesidad. Entre nosotros, más que en parte alguna, todos los males de las viejas formas de la Universidad se producen libremente sin que se conozcan asimismo sus bienes (si es que estos existen). Por eso es que en la obra de la reconstrucción de las instituciones educacionales superiores se encuentran unidos los pensamientos de todos los que de estos asuntos se preocupan, sin que les separen las diferencias de detalles, las pequeñas cosas que -una vez realizada la reforma- trataran los diversos grupos de que se implanten pero en forma rápida y decisiva, a hacer del viejo esqueleto, del armazón oxidado un organismo vigoroso apto y eficaz. 